\title{
O PODER PROVINCIAL: POLÍTICA E HISTORIOGRAFIA
}

\author{
Miriam Dolhnikoff ${ }^{1}$
}

RESUMO: Este artigo parte da análise da obra de Sérgio Buarque de Holanda dedicada à história polftica brasileira do século XIX, para examinar o significado da criação do poder provincial, entendendo-o como um momento estratégico na viabilizaçâo do Estado Nacional brasileiro, que teve de acomodar no seu interior, ao longo do processo de sua constituiçáo, as oligarquias regionais, conciliando forças centrifugas e centralização.

Sérgio Buarque de Holanda dedicou parte de sua vasta obra à história política brasileira do século XIX, examinando, através de abordagem bastante original, o processo de construção do Estado brasileiro. Seu ponto de partida foi descartar a imagem da independência como luta nacional contra o dominío português, como se a nação já existisse ou nascesse neste momento. Escapou, assim, da armadilha de considerar o Estado Nacional mera continuidade do aparelho burocrático lusitano transplantado para o Brasil em 1808. Ampliou, portanto, as possibilidades de investigação, desvendando-nos um longo e conflituoso processo, no qual o Estado se foi, aos poucos, constituindo.

Nosso propósito é perscrutar, no conjunto do seu trabalho, dedicado a esse período, o significado da criação das Assembléias Legislativas Provinciais, em 1834, através do Ato Adicional, de modo que as províncias passaram a gozar de certa autonomia financeira e administrativa. A viabilização do projeto de integrar todas as ex-colônias lusitanas em torno de um único centro de decisões dependia da sua imposição ao regionalismo exacerbado herdado do período colonial. Isto só foi possível, ao nosso ver, lançando-se mão do recurso à institucionalização

1 Pós-graduanda em História Econômica, DH-FFLCH/USP. 
DOLHNIKOFF, Miriam. O poder provincial: politica e historiografia.

de um conflito que acabou por adentrar a República: o enfrentamento entre oligarquias regionais e governo central, através do poder provincial, embriấo dos poderosos estados da República.

O texto "A Herança Colonial-Sua Desagregação" ${ }^{2}$ aponta para as duas principais forças em confronto desde a instalação da Corte portuguesa no Rio de Janeiro: o antigo impulso, identificado com os localismos, a desvinculação entre as diversas regióes americanas colonizadas por Portugal; e um novo, a tendência à centralização político-administrativa. Deste embate resultou o próprio Estado Nacional. Não que o intuito de permanência estivesse ausente na ação dos homens que promoveram a independência. Oriundos dos únicos setores sociais aptos a levá-la adiante - a aristocracia agrária e burocratas reinóis - seu objetivo foi justamente o de preservar uma organização econômica que os beneficiava. Mas, por paradoxal que pareça, viram-se, por isso mesmo, empenhados em promover mudanças imprescíndiveis para a manutenção de seus privilégios, de tal sorte que, em toda a primeira metade do século XIX, o Brasil foi palco do imenso esforço para garantir a existência de um Estado forte, centralizado, capaz de ser fiador da continuidade desejada.

Sérgio Buarque de Holanda empenha-se em distinguir dois momentos no caminho percorrido para conservar as instituições e a organização econômica colonial. De um lado, o processo de emancipação política, finalizado em 1831, que não trouxe em seu bojo uma "consciência nacional" e nem apresentou forças próprias para forjar, na luta pela independência, uma nação. Introduziu, apenas, a tendência à centralização político-administrativa, desencadeada a partir do Centro-Sul. Quanto ao outro processo, de unidade nacional, o autor frisa que

"... por vezes, mas' nem sempre, se deixa confundir com esse, e que tem em mira uma unificação cabal das partes diferentes em que se dividia a monarquia portuguesa deste lado do Atlantico. Apesar dos governadores-gerais e dos vice-reis, já não será tão exato pretender que encontra seu término no final do primeiro reinado. Pois

2 HOLANDA, Sérgio Buarque de. A Herança Colonial-Sua Desagregação, in História Geral da Civilização Brasileira, org. por S. B. de Holanda, 6 ed.. São Paulo: Difel, 1985, t. II, v.1, p. 9 a 39. 
R. Histórla, São Paulo, n. 122, p. 71-95, jan/jul. 1990.

não é durante a Regência e, ainda, nos oito ou nove anos que se seguem à Maioridade, que forças centrífugas latentes, capazes de, sem um freio, levar à desintegração do Império bragantino na América, se fazem mais ruidosamente manifestas? Se fosse possível marcar mais nitidamente o remate do processo tendente à unidade nacional, depois da dispersão, caberia talvez situa-lo por volta de 1848, o ano em que nossos liberais quebram os remos ${ }^{\prime \prime 3}$.

Detendo-se na análise do processo pelo qual a Corte instalada no Centro-Sul conseguiu impôr-se às demais regiōes, Maria Odila da Silva Dias, oferece uma interpretação bastante esclarecedora de como "a corte do Rio lançou os fundamentos do novo império português chamando a si o controle e a exploração das outras 'colônias' do continente, como a Bahia e o Nordeste" ${ }^{4}$. A centralização surgia como única forma de assegurar a desejada continuidade da economia colonial, pois proporcionava meios para enfrentar os problemas que afligiam a classe dominante. Especialmente o pânico de que uma revolta escrava incontrolável colocasse em risco sua dominação, levando os proprietários rurais a se protegerem sob o manto de um Estado forte, o que requeria a unidade e não a dispersão:

"O sentimento de insegurança social e o 'haitianismo', ou seja, o pavor de uma insurreição de escravos ou de mestiços como a que se dera no Haiti em 1794, agiu como força política catalisadora $e$ teve um papel decisivo no momento em que regionalismos $e$ diversidades de interesses poderiam ter dividido as classes dominantes da colônia" ${ }^{\prime 5}$.

A necessidade de enfrentar forças centrífugas poderosas, no entanto, exigia do Estado, como nota Sérgio Buarque de Holanda, legitimidade para reprimir revoltas e movimentos separatistas, ao mesmo tempo em que cooptava as

3 Ibidem, p. 15.

4 DIAS, Maria Odila da Silva. A Interiorização da Metrópole. In: Carlos G. Mota (org.). 1822 Dimensöes. 2a. ed.. Sâo Paulo: Perspectiva, 1986, p.173. 
DOLHNIKOFF, Miriam. O poder provincial: política e historiografia.

oligarquias regionais. Esta legitimidade foi conquistada conferindo-se ao governo central uma aparência de representatividade; de que o

"...regime tinha a seu favor a vontade popular expressa em número apreciável de sufrágios. Era preciso, entretanto, retirar do nada, ou do quase nada, os eleitores e elegíveis e, para tanto, recorreu-se principalmente a uma farta distribuição de empregos públicos" ${ }^{\prime \prime}$.

Esta solução tornou-se plenamente factível a partir de 1831, quando a abdicação de D. Pedro I permitiu ao aparelho de Estado desvencilhar-se dos portugueses, ficando os cargos públicos disponíveis. Com isso "as classes desprovidas de meios para uma subsistência decorosa segundo os padrōes dominantes e que normalmente poderiam pesar sobre o Tesouro, viram convertidas suas próprias necessidades em prerrogativas" ${ }^{7}$. Houve, assim, uma perversão da noção de representatividade, criando-se "

"... um sistema sui generis em que, para salvar-se a fachada parlamentarista, o governo há de depender, ao menos teóricamente, da vontade dos representantes da nação, mas onde os representantes da nação vão depender por sua vez da vontade do governo. A Câmara eletiva, principalmente, torna-se verdadeiramente um corpo de fiscais fiscalizados ${ }^{\prime 8}$.

Tal o expediente encontrado para suprir as lacunas herdadas da organização preexistente, que se queria preservar.

Constrói-se, então, um Estado de funcionários públicos, cuja dinâmica tem por único ponto de estabilidade o poder pessoal exercido pelo Imperador. Seus mecanismos de funcionamento são comparados por Sérgio Buarque de Holanda aos constantes motins que ocorriam entáo no restante da América Latina. $\mathrm{O}$ Guarda Nacional. 2a. ed.. Sảo Paulo: Nacional, 1979, p. XXI.

7 HOLANDA, Sérgio Buarque de. Do Império à República, HGCB. 4a. ed.. São Paulo: DIFEL, 1985, t.II, v.5, p.83.

8 HOLANDA, Sérgio Buarque de. Prefácio à Milicía Cidadã. Ob. cit., p. XXI. 
gabinete escolhido pelo detentor do poder moderador, para ter condiçóes de governar, mantendo a aparência de representatividade, ao mesmo tempo em que se curvava às vontades imperiais, via-se compelido a promover a demissão em massa dos funcionários, substituindo-os por outros de sua confiança, enquanto que, por outro lado, de acordo com o "espírito do regime", obtinha a maioria parlamentar através da dissolução da Câmara temporária e da convocação de eleiçóes, onde a fraude e a violência impunham um resultado favorável ao ministério.

Colocava-se em pauta, portanto, a necessidade de disciplinar e subordinar ao governo central os potentados locais, estabelecendo-se entre ambos uma espécie de consórcio, que permitia ao primeiro o acesso à imensa clientela subordinada aos proprietários rurais, sem a qual não seria possível o falseamento das eleições, imprescíndivel para o funcionamento do sistema. Assim,

"... durante a Regência, exatamente quando o poder tende a ser contestado e os governos centrais vão depender de influências de localidades, animadas muitas vezes e alimentadas, pelos mesmos governos, é que se produzem as condições para a distorção mais acentuada dos princípios democráticos ${ }^{\prime 9}$.

É esclarecedora, nesse sentido, a descrição das chamadas "eleições do cacete", funesto marco da ordem "representativa" que então se instaurava, feita pelo historiador Paulo Pereira de Castro,

"... Tratou-se inicialmente de substituir o pessoal que seria encarregado de fiscalizar as eleições. São nomeados novos presidentes para as províncias, são removidos juizes de direito $e$ chefes de policia, são suspensos oficiais superiores da Guarda Nacional e aos substitutos destes é ordenado o recrutamento de 4000 novos guardas. Decretou-se o recrutamento às vésperas das eleições e finalmente suspenderam-se os juízes de paz que presidiam o pleito. Passou-se, depois, à violência. Maltas de valentões, com a conivência da polícia, quando não dirigidos por ela, assaltavam as mesas

9 Ibidem, p.81. 
DOLHNIKOFF, Miriam. O poder provincial: política e historiografia.

eleitorais. (...) A fraude completa o quadro dessas eleições. $\mathrm{Na}$ qualificação dos eleitores aceita-se meninos, escravos, pessoas imaginárias e trocas de identidade. No momento do recolhimento dos votos, os eleitores de paróquia são impedidos de votar e as urnas enchidas com votos preparados. Noutros casos, o conteúdo das urnas é substituído. Frauda-se a apuração com a alteração na contagem dos votos, com a falsificação das atas e, finalmente, no ato de qualificação do eleitor de província" ${ }^{10}$.

Estes procedimentos seriam impensáveis sem a colaboração ativa daqueles que detinham a imensa clientela que habilitava o governo central a intervir de forma tão direta nas mais distantes localidades.

Por outro lado, como nota Maria Odila da Silva Dias, as reformas liberais da Regência, nas quais se incluíam a criação do cargo de juiz de paz eletivo e do júri,

"... viriam desencadear as forças de desagregação do mandonismo local, exacerbando as lutas entre faç̧ões locais, o que as faria recorrer como solução de desespero a um compromisso ou entendimento com o poder central ${ }^{\prime 11}$.

Tornou-se possível um acordo que interessava a ambas as partes, cabendo ao poder central evitar que prevalecesse a inteira privatização da dominação, adotando, para isso, medidas capazes de corrigir o curso imprimido até ao momento pela Regência: a Lei de Interpretação do Ato Adicional e a Reforma do Código de Processo Criminal retiraram do poder local as atribuições judiciais e policiais, centralizando-as nas mãos do governo sediado no Rio de Janeiro.

Os construtores do Estado tiveram ainda, segundo Sérgio Buarque de Holanda, de anular os orgãos que, durante três séculos, deram vazão ao localismo: as Câmaras Municipais, cujo aniquilamento foi feito progres-

10 C.ASTRO, Paulo Pereira de. A Experiência Republicana, in HGCB. 5a. ed.. São Paulo: Difel, 1985 , t. II, v.2, p.65.

11 DIAS, Maria Odila da Silva. Ideologia Liberal e Construção do Estado no Brasil in Anais do Museu Paulista, São Paulo, t.XXX, p.222, 1980/81. 
sivamente, inserindo-se no quadro mais largo da liquidação da herança colonial. O primeiro passo foi dado em 1824 com a Constituição outorgada, seguido pela lei do 1828, que esvaziou totalmente de conteúdo político e de recursos financeiros esses organismos, ao regulamentá-los de modo a vinculá-los profunda e rigorosamente ao governo central. A pá de cal, entretanto, foi dada pela criação, em 1834, das Assembléias Legislativas Provinciais que, se de um lado consagraram o regionalismo no seu ambito provincial, liquidaram, por outro, o poder municipal, pois a este não era permitido sequer contratar um empregado sem a autorização da Assembléia. A partir deste instante ế nela que se passa a aninhar o princípio de autonomia regional.

Em que pese as divergências dos políticos da época, tanto conservadores como liberais pareceram estar de acordo com a necessidade de reorganizar as instituições locais. Não só sua ação, uma vez no poder, como também as obras deixadas por seus representantes mais ilustres, evidenciam a percepção de que o fim das Câmaras Municipais era condição para adequar o regionalismo às exigências do Estado Nacional que se foi aos poucos constituindo. Uma leitura menos atenta poderia induzir à conclusão de que, na acirrada polêmica travada entre os dois partidos, os conservadores, como críticos pertinazes do Ato Adicional, colocavam-se na defesa dos municípios que, segundo eles, teriam sido injustamente sacrificados no altar do poder provincial. Nestes têrmos manifesta-se um dos seus mais importantes porta-vozes, o Visconde do Uruguai:

"... Ficaram as C'âmaras Municipais, pelo Ato Adicional mais peadas que antes e, à tutela em que estavam dos presidentes de provincia, acresceu a rigorosíssima das Assembléias provinciais. (...) Não temos nas provincias verdadeiras municipalidades. Foram entregues amarradas às Assembléias provinciais" ${ }^{12}$.

Do outro lado, um federalista convicto, Tavares Bastos, rebatia as acusações, em nome dos liberais, afirmando que a reforma constitucional de 1834 fornecia "às províncias a precisa liberdade para constituirem o seu regime

12 URugual, Visconde do(SOUZA, Paulino José Soares de). Estudos Práticos sobre a administração das Províncias no Brasil. Rio de Janeiro: Tipografia Nacional, 1865, v.1, p.VIII. 
DOLHNIKOFF, Miriam. O poder provincial: política e historiografia.

municipal, conforme as suas peculiares circunstâncias", embora reconhecesse que seu espiríto

"... era certamente investir as assembléias da superintendência sobre as câmaras; mas, na esfera das amplas faculdades relativas aos municípios, legislando sobre a sua economia, politica, funcionalismo, receita e despesa, cabia às assembléias aplicarem às localidades de cada província o sistema de governo mais proveitoso. (...) Fosse ou não acertado o sistema administrativo que as assembléias inauguravam, não se deve negar que as verdadeiras instituições locais do Brasil iam brotar à sombra do Ato Adicional" ${ }^{13}$.

O autor responsabilizava as medidas centralizadoras de 1840 e 1841 por abortarem esta tentativa e, portanto, impedirem o surgimento das novas municipalidades.

Mesmo saindo em defesa do Ato Adicional, Tavares Bastos não negava a sua contribuição decisiva para aniquilar as municipalidades, como foram herdadas do período colonial; tratava-se de criar novas instituições locais, em harmonia com a nova realidade política. Os conservadores, por seu turno, apesar das críticas que formulavam, pareceram concordar com a necessidade de manter sob controle os orgãos municipais. O fato é que, como salienta Sérgio Buarque de Holanda, de

"...pouco vale associar a este ou àquele partido a real iniciativa da mudança. A nulificação das câmaras foi atribuída constantemente aos liberais, só porque da fidelidade ao Ato Adicional, sem as reformas ou interpretações posteriores, eles farão uma espécie de bandeira de combate (...) Dos conservadores, que em 1840 procurarão revigorar o poder geral, dessa vez em detrimento das assembléias provinciais, não se pode dizer, entretanto, que deram um só passo tendente a reerguer de seu abatimento os municípios" ${ }^{14}$.

13 TAVARES BASTOS, A.C.. A Província. 2a. ed.. Sấo Paulo: Nacional, 1937, p.91.

14 HOLANDA, Sérgio Buarque de. A Herança Colonial. Sua Desagregação. Ob. cit., p.25. 
Parece-nos, assim, que, no processo de cooptação dos potentados locais e de anulação do poder de fogo das Câmaras, adquiriu caratér estratégico a criação de um poder intermediário, que, ao mesmo tempo que reconhecia o regionalismo e fornecia às diversas oligarquias um instrumento de defesa dos seus interesses, através do qual podiam entrar em confronto com o governo central, garantia, por outro lado, que este conflito não mais colocasse em risco a integridade territorial, vinculando-o institucionalmente ao Estado Nacional. O regionalismo adquiria uma nova feição, diversa do período anterior, quando prevaleciam os interesses quase exclusivamente privados dos proprietários rurais.

Uma outra solução, a centralização absoluta, já havia sido tentada durante o Primeiro Reinado, mostrando-se ineficiente, na medida em que, entre outros motivos, tornava inviável integrar um vasto território que sofria de falta de vias de comunicação minimamente razoáveis. As dificuldades advindas da ausência de uma infra-estrutura viária, que permitisse o transporte de produtos perecíveis em grande quantidade, foi um dos elementos decisivos na articulação de um Estado centralizado no Rio de Janeiro. A necessidade de organizar o abastecimento da capital funcionou como um poderoso impulso na integração do Centro-Sul ${ }^{15}$. Entretanto, persistia a dificuldade para o restante do território. A precariedade das estradas e caminhos impedia que o governo sediado no Rio de Janeiro tivesse agilidade suficiente para administrar de forma absolutamente centralizada as diversas províncias, principalmente as mais distantes. Tornou-se, entầo, premente a criação de uma instância administrativa com autonomia para atender às necessidades mais imediatas de cada região, garantindo a unidade e o Estado que a ela presidia. As Assembléias Provinciais, além de institucionalizarem um conflito que não se conseguira simplesmente eliminar, tornavam mais aceitável para as oligarquias regionais o Estado centralizado, ao conferir-lhe agilidade no atendimento de suas demandas.

Esse é o sentido das palavras de Rafael Tobias de Aguiar, ao inaugurar os trabalhos da Assembléia Legislativa paulista, em 1835, na qualidade de presidente de São Paulo:

15 Conforme desenvolveu Maria Odila da Silva Dias, no texto "A Interiorização da Metrópole", idéia que foi posteriormente retomada por Alcir Lenharo em seu livro As Tropas da Moderação. São Paulo: Símbolo, 1978. 
DOLHNIKOFF, Miriam. O poder provincial: política e historiografia.

"... Avaliando em toda a extensão a ventura que me coube de concorrer com minhas débeis forças na confeç̧ão das reformas constitucionais, esta obra verdadeiramente brasileira, que tantos bens promete à nação, já pelos meios de engrandecimento e prosperidade que outorgou a cada uma das províncias, e já pelo centro de ação e de força essencial a um grande Estado que soube conservar-se" ${ }^{16}$.

Anos mais tarde, o deputado Rodrigues Santos preocupado em defender a reivindicação de autonomia provincial feita pela agremiação a que estava filiado (o partido liberal), da acusação de fomentar o separatismo, em debate na Assembléia Legislativa de São Paulo, no ano de 1849 afirmava que,

"...(quando) colocardes as províncias tão distantes do centro, em um país tão falto de vias de comunicação, em absoluta dependência da Corte, os vexames que sofrerá o povo brasileiro amortecerão seu amor à união, pois que dela só verão os efeitos imediatos e palpáveis cotidianamente revelados pela dependência em que estão do centro ${ }^{\prime 17}$.

Ao impôr-se longas e dispendiosas solicitações à Corte para a efetivação da mais simples medida administrativa, era fatal que se tornassem atraentes idéias separatistas que permaneciam latentes, como uma ameaça constante ao império em formação. Tal "pensamento está abafado", diz ainda o deputado, referindo-se a estas idéias,

"... como a centelha debaixo das cinzas, mas que pode revelar-se e produzir um incêndio, se fôr agitado pelos excessos práticos do pensamento centralizador ${ }^{\prime 18}$.

16 SÃo PAULO, Anais da Assembléia Legislativa Provincial, v.1835-1837.

17 Ibidem, v. 1848-1849.

18 Idem. 
A constatação de que as forças centrífugas eram agudizadas pela centralização absoluta está também presente neste trecho escrito pelo Arcebispo da Bahia em suas Memórias:

"Eu mesmo, que decerto não serei suspeito de tendências para um exagerado liberalismo, não duvidei votar por ela na esperança de que as Assembléias Provinciais, longe de anarquizarem o pais, poderiam prevenir ou conter o espirito revolucionário e a cisão, que de todos os lados ameaçavam o Império, interessando-se mais de perto nos melhoramentos materiais e morais de suas respectivas provincias que, em verdade (mormente as do Norte), pouca ou nenhuma atenção mereciam dos Poderes Gerais do Estado" 19 .

O Arcebispo expressava, por esta palavras, sua perplexidade diante do aparente paradoxo de que exatamente a partir do Ato Adicional, chamado por Limpo de Abreu de "penhor da união das províncias", o separatismo se manifestasse de forma extremamente violenta, nas revoltas armadas que agitaram o período regencial. A explicação deste fenômeno deve ser buscada no caratér híbrido da reforma constitucional, fruto da negociação entre a Câmara temporária, onde os representantes das oligarquias regionais estavam dispostos a aprovar um projeto radicalmente federalista, e o Senado vitalicío, que, representando os interesses do governo central, condicionou a aprovação do projeto à retirada da autonomia municipal, mantendo apenas a provincial.

Senado e Câmara dos Deputados vinculavam-se a interesses antagônicos, conforme detecta Paulo Pereira de Castro. O primeiro estava afastado dos interesses locais, pois o recrutamento dos seus componentes

"... era feito normalmente entre os membros do ministério em exercício e por isso ele reunia as grandes experiências administrativas que tendiam normalmente a libertar-se de vinculações locais, já por sua experiência em plano geral, já porque

19 Citado por Sérgio Buarque de Holanda in A Herança Colonial. Sua Desagregação. Ob. cit., p.18. 
DOLHNIKOFF, Miriam. O poder provincial: política e historiografia.

DOLHNIKOFF, Miriam. O poder provincial: polf́tica e historiografia.

deviam suas cadeiras à máquina do governo central e não às ligações políticas provinciais. (...) Os senadores se diziam enfaticamente senadores da Nação e repeliam como uma diminuição de dignidade $o$ conceito de senador por uma Província" ${ }^{20}$.

Os deputados, por sua vez, eram eleitos pelas províncias e, paralelamente às divisões ditadas pela filiação partidária, agrupavam-se de acordo com sua origem regional. Não causava estranheza, por exemplo, que liberais do Norte antagonizassem com liberais do Sul em torno de questóes que envolviam interesses divergentes de cada região.

"... As diferenças ideológicas entre os liberais do Norte e os liberais do Sul eram em parte compensadas pelo interesse comum em conduzir o governo de tal forma que melhor assegurasse o predominto de cada grupo em seu âmbito provincial. O primeiro resultado disso é a tendência para que as bancadas das grandes províncias passassem a constituir blocos autonómos interessados primordialmente nos seus interesses provinciais" ${ }^{21}$.

Nesta perspectiva, parece-nos procedente afirmar que as Assembléias Legislativas Provinciais e o Parlamento complementavam-se na defesa dos interesses das oligarquias regionais, apesar dos deputados gerais serem majoritáriamente funcionários públicos e, portanto, subordinados ao Executivo. Isso podia limitá-los, mas não ao ponto de os impedir de honrar seus compromissos com suas províncias. Uma representação enviada pela Assembléia Legislativa de São Paulo ao governo central, em 1841, reflete claramente esta concepção quando, ao protestar contra os rigores do recrutamento a que vinha sendo submetida a população paulista, propõe

"...que o número de recrutas exigidos para a formação do exército do Império seja repartido pelas províncias na proporção do 
R. História, São Paulo, n. 122, p. 71-95, jan/jul. 1990.

número de deputados que cada uma delas envia à Assembléia Geral. Sendo um princípio inegável de justiça que os ônus devem ser proporcionais às vantagens que se colhem do contrato social, e estas vantagens relativas à parte que cada uma das províncias toma na decisão dos negócios gerais, o que fica evidente pelo número de deputados que nomeia, parece que semelhante regra deve ser adotada como a mais justa" ${ }^{22}$.

O poder provincial detinha, todavia, a primazia na defesa dos interesses regionais, o que não contradizia em absoluto seu papel de instrumento de viabilização do Estado Nacional, graças ao desempenho da função de intermediário reconhecido por ambas as partes, acomodando-as numa convivência conflituosa, mas que afastava o perigo da fragmentação; intermediário no sentido de servir às oligarquias regionais, ao mesmo tempo que as vinculava ao aparelho burocrático sediado no Rio de Janeiro. Feijó foi talvez um dos políticos que teve a percepção mais aguda dessas circunstâncias ao pretender erguer um sistema em que localismo e autoritarismo do governo central cohabitassem.

"... Feijo, um exaltado entre os moderados, (...) sempre se comportou muito menos como um parlamentarista do que como um presidencialista à americana, no resistir constante à preeminência da câmara temporária na ação executiva, de que dará mostras eloquentes quando regente do Império, e no favorecer as autonomias provinciais que queria ainda mais amplas do que o estabelecido no Ato Adicional" ${ }^{\prime 23}$.

A proposta do regente, de que o governo central se relacionasse diretamente com as Assembléias Legislativas, foi, no entanto, vencida e acabou prevalecendo a acomodação das oligarquias regionais em duas instâncias: nas Assembléias Provinciais e no Parlamento.

22 SÃo PAULO, Anais da Assembléia Legislativa Provincial. v.1840-1841.

23 HOLANDA, Sérgio Buarque de. Prefácio à Milicía Cidadã, op. cit., p. XVIII. 
DOLHNIKOFF, Miriam. O poder provincial: política e historiografia.

A precedência do poder provincial na defesa dos interesses regionais, ao nosso ver, residia na capacidade dos seus orgáos legislativos de responder agilmente às demandas mais imediatas do território sob sua circunscrição. $\mathrm{O}$ exemplo talvez mais contundente foi o de São Paulo, onde uma economia bastante peculiar cresceu à sombra da imponente presença da Serra do Mar, situada entre o planalto e o Atlântico, como um obstáculo, aparentemente intransponível, ao desenvolvimento de uma agricultura de exportação que almejava atingir o vigor da produção do Nordeste. Originou-se, assim, a vocação paulista de desbravamento do interior, que redundou num rico comércio interno, visando principalmente o abastecimento do Centro-Sul; a distribuição para grande parte do Brasil do gado gaúcho que chegava a Sorocaba, integrando o Sul do país ao restante do território nacional (pois entre o Rio Grande e São Paulo houve o desenvolvimento de uma zona que se especializou em fornecer invernada para o gado que se dirigia a Sorocaba), e, mais tarde, graças à paulatina construção de estradas, desenvolveu-se a agricultura de exportação, com uma pauta de produtos os mais variados, incluindo, além do café e do açúcar, arroz, algodão, couro, etc.

Nesse contexto, adquiriu grande importância, para a economia paulista, a construção de estradas e caminhos pelos quais pudessem circular seus produtos, tanto em direção ao interior como em direção ao mar. Em

"... São Paulo, os caminhos - e refiro-me sobretudo aos caminhos terrestres, atalhos de pé posto ou estradas seguidas - não tiveram como em tantas regiões um papel pouco mais do que subsidiário, não foram meros auxiliares da lavoura ou da criação, mas exerceram uma função histórica fundamental ${ }^{24}$.

Os caminhos foram a própria condição de sobrevivência e de desenvolvimento da região. Tarefa por demais gigantesca para fazendeiros isolados, coube à Assembléia Provincial a criação de uma rede viária capaz de fazer frente às necessidades da economia paulista. É neste sentido que se expressa o deputado Carneiro de Campos, ao encerrar, em 1841, na qualidade de

24 HOLANDA, Sérgio Buarque de. Índios e Mamelucos na Expansão Paulista. Anais do Museu Paulista, XIII, p.178, 1949. 
R. História, São Paulo, n. 122, p. 71-95, jan/jul. 1990.

seu presidente, os trabalhos da Assembléia de São Paulo, afirmando que o escrupuloso respeito daquela casa

"... às leis orgânicas e gerais do Estado, a sua harmonia e lealdade para com os supremos poderes nacionais tem sido para os povos de salutar exemplo. Possuidas desse espirito as legislaturas dessa província, e pesando bem a razoada e verdadeira missão das Assembléias Provinciais, e as necessidades públicas, elas parecem ter compreendido que o progresso e futura opulência da província dependem sobretudo da facilidade de transporte dos produtos de indústria (...) Tudo entre nós, como já observei, é novo e começa: assim, todos os melhoramentos de vias de transporte dependem da ação do poder público" ${ }^{\prime 25}$.

Sérias dificuldades, no entanto, se apresentavam para o desempenho de tarefa de tamanha envergadura, principalmente a falta de cabedal suficiente. Em 1844, o Presidente de São Paulo defendia a necessidade de um planejamento, por parte do governo, da construção e manutenção das estradas, de modo a atender as principais prioridades, uma vez que os cofres públicos não se encontravam em condições de atender toda a demanda deste setor. Segundo ele, em uma província tâo extensa,

"... contando de norte a sul mais de duzentas léguas, e outras tantas de leste a oeste, de primeira e mais palpitante necessidade é a abertura e conservação de estradas que ponham em comunicação entre si os diferentes municípios espalhados por essa área imensa, tornando possível e fácil a circulação de idéias e produtos, destarte aumentando a indústria, o comércio e a civilização de seus habitantes: esta necessidade tem sido seguramente sentida pelas Assembléias e administrações passadas, mas creio não se poder também afirmar que tivessem aplicado as medidas mais eficazes para provê-la de remédio. De primeira intuição é a conveniência de um plano estudado e fixo de estradas que, passando por certos $e$ 
DOLHNIKOFF, Miriam. O poder provincial: política e historiografia.

determinados pontos, levem e promovão a vida aos estabelecimentos que estão em embrião ou já desenvolvidos e que, ao mesmo tempo, demanda em menores gastos e prestem-se ao serviço do maior número de municípios" ${ }^{\prime 26}$.

As dificuldades enfrentadas pelo governo provincial, em virtude da desproporção entre os recursos administrativos e a região a ser atendida, dão mostras da impossibilidade de que o governo central assumisse este encargo em relação a todo o território nacional.

Nesta questão transparece outro elemento decisivo para compreender o papel que a Assembléia Legislativa desempenhava no sentido de reduzir a distância político-administrativa entre a capital do Império e as províncias: o conhecimento que os deputados provinciais detinham da região, pois, geralmente, eram nela nascidos ou lá tinham seus principais negócios, ao contrário do presidente, indicado pelo governo central, estranho à província $\mathrm{e}$ nela permanecendo um período muito curto. Os deputados estavam, portanto, melhor aparelhados para indicar as soluções mais adequadas aos problemas que se apresentavam, para atender às demandas mais prementes da oligarquia regional e, assim, estabelecer uma conciliação que impedisse o surgimento de sentimentos separatistas ou de alguma forma contrários ao Estado Nacional. Este é, por exemplo, o sentido das palavras do Presidente de São Paulo, ao dirigir-se à Assembléia Provincial em 1843, quando explica que seu relatório sobre o estado das estradas se baseou em informações fornecidas pelos municípios.

"Essas informações, sobre as quais fundamentei os pedidos que faço no orçamento, e que vos serão presentes, dispensam-me de inserir no relatório a lista quase interminável dessas precisões, a maior parte delas muito reais, mas que não é possivel que sejão todas satisfeitas, e que só submeto a vossa consideração para que façais a devida seleção, ajudados dos conhecimentos que tendes das diferentes localidades, conhecimentos 
que raras vezes pode obter o governo, por mais informações que procure $^{\prime 27}$.

Além disso, tal conhecimento tornava possível que se respeitassem minimamente as especificidades regionais. Tamanha era a importancia das Assembléias Legislativas neste ponto que, quando a divisão administrativa incluía numa mesma província duas regiōes com características distintas, era quase inevitável uma permanente tensão. Foi o que ocorreu pelo menos no caso de São Paulo onde, com a expansão cafeeira; cristalizaram-se duas regiões profundamente diversas entre si: o Vale do Paraíba e o Oeste Paulista. A expansão cafeeira

"...chega à fase aguda só em meados do século, quando o café toma afinal o lugar do açúcar como principal genêro de exportação da Província. O processo desenvolvera-se a partir do chamado Norte, ou seja, do Vale do Paraíba, extensão natural da área cafeeira fluminense e dependente, economicamente, da Corte, muito mais do que da capital paulista. Pouco tinha a ver, pois, com a evolução da lavoura comercial na Província de São Paulo, que se efetuara de preferência na direção do Oeste, o Oeste da maior parte do século passado, que tem seu fulcro em Itu primeiramente, depois em Campinas" $^{28}$.

Uma das maiores consequências da distinção entre as duas regiões foi o fato de que cada qual era tributária de um porto próprio. O Vale do Paraíba escoava sua produção pelo Rio de Janeiro, enquanto o Oeste paulista utilizava-se de Santos. Sérgio Buarque de Holanda chama atenção para o depoimento de um técnico holandês, C. F. Van Delden Laerne, que veio ao Brasil a serviço de seu governo em 1883, e que

27 Ibidem, v.1842-1843.

28 HOLANDA, Sérgio Buarque de. São Paulo. In: HGCB. 5a. ed.. São Paulo: Difel, 1985. t.II v.2, p. 461. 
DOLHNIKOFF, Miriam. O poder provincial: política e historiografia.

"...não hesita em dar à parte do noroeste e do oeste de São Paulo o nome de 'zona de Santos', contrastando-a com a zona do Rio de Janeiro, que abrangeria toda a bacia do Paraíba, inclusive no território paulista. Não escapa mesmo ao atilado observador a rivalidade existente entre as duas zonas, e cita o caso de um fazendeiro do oeste que, em sua presença, procurou desconcertar outro, do Vale do Paraiba, dizendo que na primeira zona um só arbusto dá três vezes mais café do que três da outra. 'A comparação', observa, 'é um tanto... paulista demais, embora o fazendeiro do Rio guardasse silêncio, e deixasse, assim, mais ou menos ganha a partida para o contendor'. Mas concorda o viajante em que a zona 'de Santos' produzia ao menos quase duas vezes mais do que a 'do Rio'" 29 .

O que desejamos sublinhar é que foi com o Oeste da província que a Assembléia Legislativa de São Paulo se identificou, e foi com o desenvolvimento de sua agricultura de exportação que ela se comprometeu, construindo uma rede viária capaz de escoar a produção até o porto de Santos pelo menor custo possível. A relação que desenvolvera o Vale do Paraíba com o governo do Rio de Janeiro, quando do inicío de sua ocupação pelo café, no começo do século, foi, assim, substituída, no planalto, pelo desempenho do poder provincial. Este teve como prioridade transpôr o obstáculo representado pela Serra do Mar, para que os genêros agrícolas chegassem a Santos em boas condições. A crer nas várias reclamações presentes em representações de algumas Câmaras Municipais, a Assembléia paulista permaneceu, indiferente às demandas do Vale do Paraíba.

A única alternativa que restou ao Norte de São Paulo foi reivindicar do governo central o reconhecimento de que, como região tributária do Rio de Janeiro, ser-lhe-ia mais vantajoso a sua anexação a esta província - da forma solicitada pelas vilas de Bananal e Areias, em 1843; naquela altura, apresentara-se um parecer da comissão de estatística ao plenário da Assembléia Legịslativa paulista, refutando as acusações de que esses

29 HOLANDA, Sérgio Buarque de e MAIA, Tom. Vale do Paraíba: Velhas Fazendas. São Paulo: EDUSP, 1975, p.41. 
R. Mlstorla, São Paulo, n. 122, p. 71-95, jan/jul. 1990.

"...municípios somente sabem que pertencem à provincia de Sâo Paulo, quando tem de cumprir as ordens do governo, porque esta Assembléia não tem olhado com a devida atenşa para eles: $e$ ale sendo a provincia do Rio de Janeiro rica e industriosa, e tendo a foriuna de possuir uma Assembléia Provincial ilustrada e patriótica tem colhido methoramentos materiais, o que näo sucede a seu municipio".

A contssão afirma que o desmembramento nțo traxia nenhuma mudança, pors as lełs por mass sábias e prudentes que sejăo não poder converter a Indolencia en amor ao trabalho e o hábito rotineiro da indústria em espirto de irvença to $e$ melhoramento industrial ${ }^{30}$, respousabilizando claramente ats caracterís ticas da produção cafeeira do Vale, no que se distinguiam das do Oeste, pelas diftcudades que a regiäo enfrentava.

Outra solução axentada foi a de que o Vale do Parába fosse elevado a categotia de Provincia, com Assembléia Legistativa própria. En 1829, foi tutvndicada a criação da província de Rezende e, na década de 80, foi proposta a formaça da província do Rio Sapucar. Sérgio Buarque ale Holanda expliciá o signiflcado desses vários movimentos:

$$
\text { ".... Entre as mais curiosas manifestaçóes de }
$$

inconformismo suscitado pelo espetáculo de uma paisagem rural que, empobrecida, embora, orgulhava-se ainda da riqueza e pompa de um passado relativamente recente, merece ser citado o renascimento de certas manifestaçóes seccionistas no vale do Paraiba paulista. Dliava-as, como em casos anteriores, a impaciência diante das deslgualdades económicas flagrantes. A diferenģa está, contudo, em gue naqueles outros casos o que se pretendera principalmente era tibertar o 'norte' de uma tutela, a de São Paulo, que parecia, com seu 'atraso', cencear a prosperidade e opulência de que desfrutavam as terras da bacia do Paraba; assim foi em 1829 quando se chegou a levantar a bandeira de uma 'provincia de Rezende' a englobar, entre outros, mais de um município paulista, ou por varias vezes, as 
DOLHNIKOFF, Miriam. O poder provincial: política e historiografia.

aspirações dos de Bananal no sentido de separar-se seu distrito para ser anexado à província fluminense. Agora, ao contrário, é a opulência e prosperidade insofismáveis do novo oeste que, aos paladinos da antiga preeminência do vale do Paraíba, se apresenta como fruto de injustiças e opressões, que só o desmembramento poderia sanar. A solução estaria, pois, em formar-se uma 'provincia do Rio Sapucaí', que abrangeria, com o 'norte' de São Paulo, boa parte do território sul-mineiro" ${ }^{\prime 31}$.

A paternidade deste último projeto foi do senador Joaquim Floriano de Godoi que, já em 1872, afirmava ser a decadência do vale "obra do governo provincial que, ajudando com liberalidade outras partes da província, vinha negando sistemáticamente assistência àquela que, em tempos mais felizes, fora entre todas a mais rica e produtiva" ${ }^{32}$. Quando da defesa de sua proposta, foi ainda mais enfático, acusando as autoridades provinciais de destinarem todas as verbas para o Oeste, enquanto ao Norte da província eram jogadas "umas vitualhas orçamentárias, e isto mesmo com o mau humor com que se arremessa à sacola do importuno mendigo, esmola de má vontade" ${ }^{33}$.

A discrepancia entre as duas partes da província agudizou-se com a falta de mão-de-obra para a lavoura, pois, enquanto os fazendeiros do Oeste paulista se empenharam na vinda de trabalhadores europeus, o Vale do Paraíba apegou-se desesperadamente ao braço escravo. Sob este ângulo, fica patente que as especificidades tinham suas raízes no processo particular de colonização e desenvolvimento de cada região: a proposta imigrantista era consoante com a tradição paulista mais longínqua e não há, portanto, porque

"...estranhar esse empenho em ir procurar braços para a lavoura onde quer que existissem, se precisamente tal empenho

31 HOLANDA, Sérgio Buarque de. Vale do Paraiba: Velhas Fazendas. Ob. cit., p. 42.

32 Citado por Sérgio Buarque de Holanda in Do Império à República. Ob. cit., p.277.

33 Citado por Sérgio Buarque de Holanda in Vale do Paraiba: Velhas Fazendas. Ob. cit., p. 42. 
explica toda história paulista desde meados do século XVI, quando Diogo Dias e Afonso Farina iam de S. Vicente a Assunção do Paraguai negociar 'peças da terra,"34.

Esses incidentes refletem claramente a importância do poder provincial para o desenvolvimento das potencialidades da "pátria paulista", a ponto de causar forte ressentimento no norte da província, que desta forma, reconhecia também a Assembléia Legislativa como instrumento eficaz de crescimento econômico ou, ao menos, como freio da decadência que se avizinhava, atribuída ao governo provincial pela atenção exclusiva que dava às necessidades específicas do Oeste paulista.

É bem verdade que o sistema constituído a partir do Rio de Janeiro esmerou-se em neutralizar essas especificidades, em ignorar as diferenças regionais em nome de princípios e idéias de ordem geral. É exemplar, neste sentido, segundo Sérgio Buarque de Holanda, a forma como foi encarado o fim da escravidăo: o governo central permaneceu oscilante entre duas propostas antagônicas de imigração, adotando ora uma, ora outra.

"...Mais justo evidentemente seria considerar os interesses próprios de cada província, de cada região, em vez de tentar adotar um critério centralizador, uniforme e inflexível, capaz de convir indiferentemente a todo o país. A essa necessidade mostravam-se cegos, porém, nossos homens de Estado, hipnotizados como sempre pela superstição unitarista e refratários a quaisquer critérios mais dóceis d̀s exigências regionais" ${ }^{35}$.

$O$ preço pago pela integridade territorial foi o de erigir-se um regime incapaz de absorver plenamente as especificidades regionais, o que acabaria por determinar o seu fim.

34 HOLANDA, Sérgio Buarque de. Prefácio às Memórias de um Colono no Brasil. Ob. cit., p.33. 
DOLHNIKOFF, Miriam. O poder provincial: política e historiografia.

Esta inflexibilidade é apontada por Sérgio Buarque de Holanda ao analisar a influência das várias regiões no governo central, no centro mesmo de decisões. Através do exame da composição dos gabinetes, onde se buscava a formação de alianças sólidas e duradouras e, portanto, permeáveis às exigências locais, o autor constata que, até a década de 1860 , as influências provinciais preponderantes eram, em ordem de importância, Bahia, Minas Gerais, Rio de Janeiro e Pernambuco. No entanto, o desenvolvimento econômico de São Paulo e do Rio Grande do Sul colocou em cheque essa "dominação tetrárquica", como a chama Sérgio Buarque, e, a partir da década de 70, tornou-se necessário contentar São Paulo e Rio Grande do Sul nas composições ministeriais.

"Entretanto a política geral não se mostrou tão pressurosa quanto seria licíto esperar, no compenetrar-se do significado de tais mudanças, destinadas a alterar toda a fisionomia tradicional do país, $e$ no procurar acompanhá-la. Nas composições dos ministérios a preponderância numérica de estadistas da Bahia continua inexpugnável ${ }^{36}$.

O Estado monárquico centralizado foi incapaz de absorver plenamente as regiões novas, econômicamente mais dinâmicas; as preferências regionalistas eram ditadas pela tradição e a Bahia decadente tinha mais força do que a rica "pátria paulista". A tarefa de garantir a integridade territorial trouxe consigo um caratér de impermeabilidade que acabou sendo um dos fatores de desgaste do regime, na medida em que exatamente um dos elementos fundamentais para afiançar esta integridade, o imenso poder pessoal do imperador, era utilizado como anteparo a qualquer tentativa modernizadora. Os poderes de que dispunha D.Pedro II funcionaram

"...como catalisadores da resistência a qualquer mudança na estrutura tradicional, quando as mudanças importavam mais do 
R. Histórla, São Paulo, n. 122, p. 71-95, jan/jul. 1990.

que un x estabilidade estéril e mentirosa. (...) Ora, a meticulosa prudên ia deixa de ser virtude no momento em que passa a ser estorvo: lastro demais e pouca vela ${ }^{\prime 37}$.

Assim, a integridade territorial e a acomodação das várias oligarquias no Estado centralizado foi, sem dúvida, uma conquista do Império, sem que, entretanto, se resolvessem satisfatoriamente as disparidades regionais. Ao entrarem em cena novas potências provinciais, ansiosas por conquistarem um poder político compatível com sua força econômica, tornou-se inevitável a adoção de um novo arranjo político, o que implicou na mudança do próprio regime.

"As' campanhas em favor da descentralização e de uma federação das províncias, não constituíam novidade no Império, mas parece indiscutivel que ultimamente haviam surgido fatores novos para que ela ganhasse outra dimensão, mormente nas partes onde a prosperidade econômica era maior, e que se sentiam asfixiadas pelo regime centralizador. O federalismo, que se exacerba ao ponto de confundir-se com o separatismo franco, é uma forma extrema de reação pela idéia de uma república federal. Não parece de estranhar, pois, se o Partido Republicano se tornou em São Paulo, muito antes, e muito mais do que nas outras províncias, uma força poderosa, coesa, organizada, apta, por isso, a assumir posição de hegemonia, ao desaparecerem, depois de 89 , os freios que limitam a expansão de suas energias" ${ }^{38}$.

Procuramos, nestas páginas, apresentar uma leitura do trabalho de Sérgio Buarque de Holanda, resgatando elementos para compreender o significado da criação das Assembléia Legislativas em 1834. Para isso, nos detivemos na análise que o autor empreende do caminho percorrido pelos homens empenhados 
DOLHNIKOFF, Miriam. O poder provincial: polftica e historiografia.

na gigantesca tarefa de construir um Estado forte, capaz de estabelecer sua dominação nos diversos territórios americanos colonizados por Portugal, impulsionados pelo desejo de manter a estrutura e as instituições coloniais. Este objetivo trouxe consigo, paradoxalmente, a necessidade de algumas transformações que encaminhassem a construção de um Estado Nacional capaz de garantir a continuidade desejada, ao mesmo tempo em que gerou contradições internas que acabaram por levar o regime ao seu fim. É no interior deste processo que deve ser entendida a constituição de um poder provincial, concessão ao regionalismo legado pela colonização lusitana, mas também instrumento de viabilização do Estado Nacional, ao fazer a ponte entre o governo central e as várias regióes sob seu dominío, graças à cooptação das oligarquias regionais, atendendo seus interesses mais imediatos e fornecendo-lhes um instrumento de participação no jogo político. Divergências e conflitos à parte, os grupos dominantes compartilharam entre si a percepção da necessidade de

"...uma arregimentação das elites para sua missão paternalista de vigilantes ilustrados de um povo bárbaro, carente de luzes, necessitado de liderança e de disciplina ${ }^{{ }^{39}}$.

O regionalismo foi incorporado ao Estado que se construía, através do poder provincial, passando a ser mais um ator no jogo político que se instaurava. Sua função precípua era a de atender as demandas mais imediatas das oligarquias regionais, de modo a sedimentar uma aliança entre elas e o governo central. Esta associação nem sempre era pacífica. Muito pelo contrário: seu custo foi o de fornecer a estes grupos um instrumento de confronto com o aparelho burocrático sediado no Rio de Janeiro, impedindo por outro lado, que este conflito ameaçasse a integridade territorial. Originalmente destinado a contribuir para a preservação do sistema escravista, o poder provincial acabou por contestá-lo, como um personagem que adquire vida própria e atenta contra seu autor.

O poder provincial foi, assim, o embrião dos poderosos governos estaduais da República Velha e é elemento fundamental para explicar a articulação entre regióes presente até hoje na política brasileira. 


\section{R. Histórla, São Paulo, n. 122, p. 71-95, jan/jul. 1990.}

ABSTRACT: This article deals with an analysis of Sérgio Buarque de Holanda's work on brazilian political nineteenth century history. The author understands the creation of provincial power as a strategic way to make viable the brazilian national state which, along the process of its formation, had to adjust with regional oligarchies, and conciliate local centripetal forces with the centralization tendency. 